\title{
末梢神経損傷後の神経再生とリハビリテーション
}

\author{
西脇香織*1 近藤 国嗣*1 里宇 明元*2 千野 直一*2
}

\section{Peripheral Nerve Regeneration after Injury and Rehabilitation Managements}

\author{
Kaori NishiwaKI, ${ }^{* 1}$ Kunitsugu Kondo, ${ }^{* 1}$ Meigen LiU, ${ }^{* 2}$ Naoichi Chino*2
}

\begin{abstract}
Peripheral nerves have a potency to regenerate vigorously after injury, but often it is difficult to achieve a sufficient functional recovery. Although advances in microsurgery and a better understanding of nerve regeneration have improved the outcomes of nerve repair, a delayed and misdirected reinnervation still be a problem hindering functional restoration. Rehabilitation managements of peripheral nerve injury, such as electrical stimulation, exercise training and other approaches, have been in clinical use, but their effects on promoting reinnervation remain controversial. In this paper we review the basic studies which have investigated the mechanisms and efficacies of electrical stimulation, exercise training and motor/sensory reeducation. Electrical stimulation could elicit effects on the regenerated nerves, but inappropriate stimulation conditions might disturb regeneration. Exercise training often improves functional recovery after nerve injury, but overloaded and forced exercise might have a detrimental effect. The peripheral axonal misdirection is reflected in a cortical reorganizational changes. Some studies have revealed beneficial changes in the cortical map after motor/sensory reeducation programs in monkeys with nerve injury, which may explain the improved functional outcomes after rehabilitation in humans.
\end{abstract}

Key words : 末梢神経再生 (peripheral nerve regeneration), リハビリテーション (rehabilitation), 電気刺激 (electrical stimulation), 運動療法 (exercise training), 知覚再教育 (sensory reeducation)

\section{はじめに}

末梢神経損傷後には旺盛な神経再生が起こるこ とが知られているが，機能回復については満足で きる結果でないことが多い.その原因として再生 の遅延や不正確性（過誤神経支配）が挙げられ る.これらの問題点に対し基礎レベルでは, 神経 再生・伸長を促進する因子の同定や，標的特異性 に関する研究が積極的に行われ，一部臨床でも応
用されつつある.一方，物理療法，運動療法とい ったリハビリテーション（以下，リハ）的手段が 神経再生に有利であるか否かについては一定した 見解が得られておらず, 臨床場面では二次的障害 予防のための関節可動域訓練や装具の作成などの 介入が中心となっている. そこで本稿では, 物理 療法 (主に電気刺激), 運動療法, および中枢性 代償としての筋再教育や知覚再教育が, 未梢神経 損傷後の神経再生とその機能回復に与える影響に 関して，基礎的な報告を中心にまとめ，臨床応用

\section{2 年 4 月 2 日受稿}

*1 川崎市立川崎病院リハビリテーション科/テ 210-0013 神奈川県川崎市川崎区新川通 12-1

Department of Rehabilitation, Kawasaki Municipal Hospital

${ }^{* 2}$ 慶應義塾大学医学部りハビリテーション医学教室/テ 160-8582 東京都新宿区信濃町 35

Department of Rehabilitation Medicine, Keio University School of Medicine 
への展望を考察する.

\section{末梢神経損傷後の神経再生の過程}

神経損傷の情報は，効果器で生成される神経栄 養因子の軸索輸送の途絶などによって細胞体に伝 わるとされ，神経再生に向けた一連の遺伝子発現 のトリガーとなる．軸索損傷による神経細胞死 （アポトーシス）を抑制する機序が働くと同時に, 損傷部より 遠位の軸索のワーラー変性が進み，変 性した組織がマクロファージやシュワン細胞の食 作用によって除去される。さらに損傷部より遠位 の神経（以下，遠位側断端）の膜構造やその周囲
に増生したシュワン細胞列（Büngner band）を 再生の足場として軸索の発芽・伸長がすすみ, 最 終的には再ミエリン化，標的組織への再結合，神 経の成熟が起こる1) (図 1). 神経細胞体の細胞死 の抑制，再生軸索の発芽・伸長の促進，再生の足 場となる構造の維持には, 血中・細胞体・グリア 細胞・シュワン細胞および効果器で生成されたさ まざまな神経栄養因子が化学的誘導因子として関 与していることが報告されている。 また, 再生軸 索の発芽・伸長には，こうした因子に加えて，再 生の足場となる構造と，接着因子などの接触誘導 因子も非常に重要な役割を担っていることが知ら れている2).

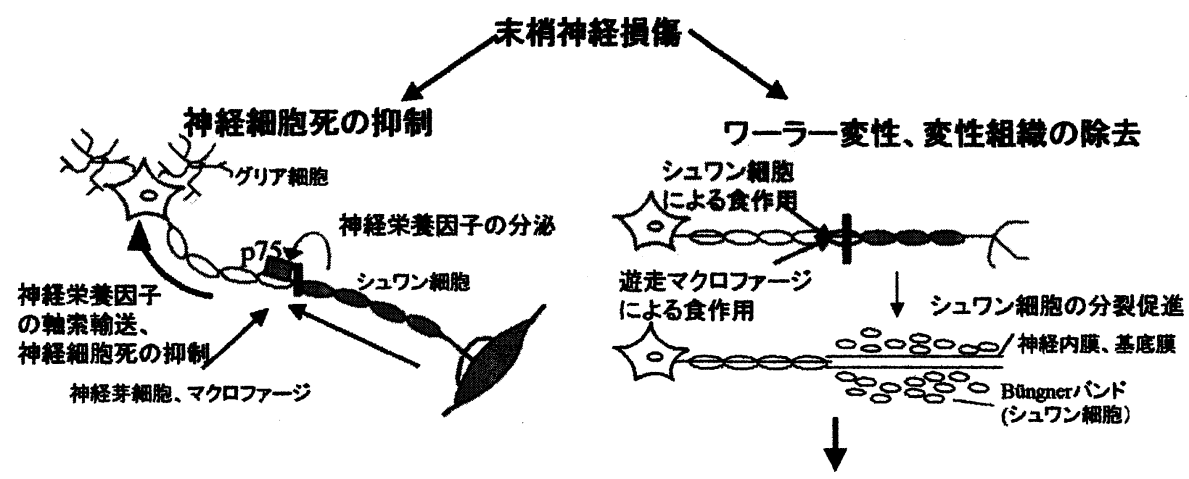

再生軸事の発芽、伸長

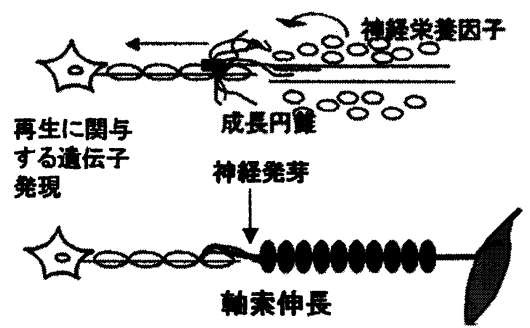

図 1 末梢神経損傷後の神経再生の過程

(1) 神経細胞死の抑制：神経損傷により，損傷部近位側断端に $\mathrm{p} 75$ （低親和性 NGF 受容体）の発現が誘導される. 細胞 体・血中の神経芽細胞やマクロファージ・損傷遠位側断端のシュワン細胞・効果器・運動細胞であれば脊髄内のグリア細 胞，で生成されたさまざまな神経栄養因子が p 75 を介して神経細胞体に輸送され，神経細胞死が抑制される。

(2)ワーラー変性，変性組織の除去：損傷部にもっとも近いランビエ絞輪から遠位にワーラー変性と呼ばれる変性が起こ る. 変性した軸索とミエリンは最初の $2 \sim 3$ 日はシュワン細胞の，その後は遊走マクロファージの食作用で処理される. 遠 位側断端は基底膜を残した管構造となり，その周囲に髄䩪非形成型に脱分化し活発に増生したシュワン細胞が並び (Büngner バンド)，再生の足場となる。

(3) 再生軸索の発芽, 伸長 : 神経損傷が細胞体で感知されると, 損傷部に最も近いランビエ絞輪部より軸索の発芽が起こ り，同部は成長円錐と呼ばれる．神経細胞体やシュワン細胞から分泌された神経栄養因子（NGF： nerve growth factor, BDNF : brain derived neurotrophic factor, NT $3 / 4$ : neurotrophin 3/4 など）が，成長円錐部のレセプターを介して細胞 体に輸送され軸索の発芽や伸長を促進する. 他にも IGF I / II (insulin like growth factor I / II) や, IL 6/1 $\beta$ (interleukins $6 / 1 \beta)$ など多くの因子が神経発芽と伸長に関わっている. 成長円錐から生じた $50 \sim 100$ 程度の幼若な発芽は多くはらせん, コイル状になって消失するが，いくつかの再生軸索は遠位側断端の管構造を足場とし，基底膜成分であるラミニンやカド ヘリンなどの接着因子の誘導で伸長していく．伸長した軸索は効果器に達すると 1 本のみとなり再ミエリン化し成熟する. 


\section{末梢神経損傷後の神経再生における問題点}

\section{1. 再生の遅延}

末梢神経損傷後の再生の過程は上記のとおりで あるが，実際には再生に時間がかかることによっ て, 再生の足場となる Büngner band の萎縮や神 経栄養因子の枯渴が生じ, さらに運動神経であれ ば神経筋接合部や筋の変性が起こり, 有効な神経 再支配や機能回復が得られないことがあり, 臨床 上問題となる2).このような例として第 1 に, 腕神 経叢損傷など, 損傷部位から効果器までの距離が 長く, 再生神経が効果器に到達するまで時間がか かる病態が挙げられる. 第 2 に, 神経切断例など で切断端の間にギャップがあり, 再生軸索の伸長 が得られない病態がある. 後者では, 再生を誘導 する足場である遠位側断端が離れているために, 発芽した神経が有効に伸長することができないと 考元られる，このような病態では，神経縫合など 外科的治療が再生を促進する有効な手段となる.

\section{2. 再生の不正確性}

末梢神経再生におけるもう一つの問題点は, 標 的特異性のない再生によって引き起こされる過誤 神経支配（misdirection）であるといえる.

運動神経と感覚神経が混在している混合神経の 切断後の再生において, 運動神経が感覚神経遠位 側断端に, 感覚神経が運動神経遠位側断端に伸長 していくと，有効な神経再支配を起こすことがで きず機能低下を引き起こす．また過誤神経支配が 感覚神経間で起きれば異常知覚の, 運動神経間で は異常共同運動など異常運動を生じる．この過䛊 神経支配の起きやすさ，神経再生時の標的特異性 についてはいくつかの異なった知見が示されてい

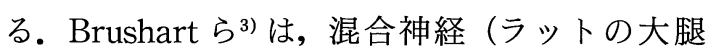
神経）を切断すると, 初期には運動神経の切断部 近位側から再生した軸索は, 運動神経遠位側断端 にも感覚神経遠位側断端にもランダムに伸長し, 正確に運動神経遠位側断端に伸長した神経, 誤つ て感覚神経遠位側断端に伸長した神経, 再生軸索 が感覚神経遠位側断端と運動神経遠位側断端の両
者に伸長した神経が同程度に認められるとした。 しかし, 時間的経過で運動神経遠位側断端に正確 に伸長している神経が増えていくとし，この現象 を “Preferential Motor Reinnervation”と呼ん だ.この機序として運動神経遠位側断端に存在す る神経栄養因子（おそらくL 2-HNK 14)）の働き で, 運動神経遠位側断端と感覚神経遠位側断端の 両者に枝を伸ばしていたような運動神経では, 感 覚神経遠位側断端へ伸びていた枝がなくなり (collateral pruning), 結果的に正しい再生をし ている神経が増えると考察した。一方, Maki ら5) は同様の実験系で, 運動神経も感覚神経も, 感覚神経の遠位側断端により多く伸長していくと し, 感覚神経遠位側断端で生成された何らかの神 経栄養因子が再生に関わっていると推測した。 Madison ら ${ }^{6)}$ は, 同じくラットの大腿神経で, 中枢寄り（腸腰筋枝より近位）で切断すると再生 はほとんどランダムであるが, 末梢寄り（四頭筋 枝と皮枝の分岐部近位）で切断すると運動神経運動神経遠位側断端, 感覚神経-感覚神経遠位側 断端, という正しい再生が $80 \%$ 程度に増えるこ とを示し, 末梢 (効果器近く) では, 解剖学的に 神経のアライメントが整っていることや, 何らか の化学的誘導因子により再生は正確になるとし た.さらに, どちらの部位の切断でも, 正確な再 生をする確率は運動神経と感覚神経でほほ等し く, 両者に共通する誘導因子の存在を示唆した. このように運動神経一感覚神経間でもその標的特 異性のメカニズムは未だ明らかでなく, 外科的に なるべく正確に縫合するという以外传有効な手段 がないのが現状である．また臨床上問題となりや すい運動神経間, 感覚神経間の過誤神経支配につ いても，できてしまった過誤支配を中枢性に代償 して機能改善を目指すことが中心となっている. これについては後のリハの項で詳述する。

\section{末梢神経損傷後の治療}

\section{1. 外科的治療}

先に述べたように, 神経再生において有効な軸 索伸長を得るには再生の足場が重要な役割を担つ 
ており，神経周膜（神経束を包む膜）を超えた損 傷では外科的な治療で損傷近位側断端と遠位側断 端を近づけることが必要とされる．正確な再生の ためになるべく神経線維の方向を揃え, 直接縫合 が可能であれば神経周膜, または神経上膜で縫合 する. ギャップが 25〜30 mm 以上できてしまう ときや, 縫合にテンションがかかってしまうとき には, 神経移植で間を埋めることが必要とな $3^{7)}$. 自家神経移植以外にも, 神経細胞の基底膜 構造を模したコラーゲンシートチューブ, 合成ラ ミニンコーティングのチューブ，シュワン細胞を 周囲に培養した重合体でつくったチューブなど, 再生の足場として有利になるように工夫された人 工的なグラフトも考案されており，実用可能性が 期待されている8).

\section{2. 神経再生促進薬, 遺伝子治療}

前述のように, 神経損傷後の再生軸索の発芽・ 伸長の促進に関与する神経栄養因子については多 くの報告がなされ, 神経再生促進薬として臨床に 応用しょうという研究も活発になされている. IGFs (insulin like growth factors) は培養細胞に おいて軸索伸長効果やシュワン細胞の増生効果を 示し, ラットでも神経切断・縫合後に縫合部に持 続的に IGF-1 を投与することによって神経再生促 進効果があったと報告され, 神経再生促進薬とし て臨床応用の可能性があると注目されている ${ }^{9}$. しかし，他の神経栄養因子（NGF や NT-3/4 な
ど）では，生体での神経再生促進効果を認めなか つたという報告も多い1)。また， adenovirus をべ クターに用いて神経細胞やシュワン細胞に安定し て遺伝子を導入し得たという報告もだされ ${ }^{10)}$ ，再 生に有利な神経栄養因子の遺伝子を導入するよう な遺伝子治療の可能性も示唆されている.

\section{3. リハビリテーション}

1）電気刺激

電気刺激は末梢神経障害に対し，除痛 (Transcutaneous Electrical Nerve Stimulation, TENS）や機能的電気刺激（Functional Electrical Stimulation, FES)，または脱神経筋刺激と しても使われているが，本稿では損傷神経そのも のに対する電気刺激が神経再生・軸索伸長に与え る影響についての報告をまとめた。

\section{（1）直流電気刺激と神経再生}

培養神経細胞に直流電流を与えて電場を作ると その陰極方向に軸索突起が伸長していく現象は 1970 年代より報告され，細胞表面の糖蛋白や， 蓄積されている細胞骨格成分が電気泳動の原理で 陰極に誘導され，整列していくことにより起こっ ていると考察されていた ${ }^{11)}$. 培養細胞によるこれ らの報告から, 生体の神経損傷モデルで, 直流電 流を陰極が伸長方向になるように流すことでより 早い神経再生が誘導できるのではないかと考えら れ，1980 年代後半から 1990 年代前半にかけて, いくつかの動物実験が行われた。それらの結果を

表 1 直流電気刺激と神経再生

\begin{tabular}{|c|c|c|c|c|}
\hline $\begin{array}{ll}\text { 報 } & \text { 告 } \\
\end{array}$ & 実験モデル & 刺激条件 & 評価法 & 総合評価 \\
\hline McDevitt $^{12)}, 1987$ & $\begin{array}{l}\text { ラット, 坐骨神経 } \\
\text { 切断・縫合 }\end{array}$ & $\begin{array}{l}\text { 陰極を損傷部より遠位 } \\
\text { (神経伸長方向), } \\
10 \mu \mathrm{A}, 30 \text { 分/日，40日間 }\end{array}$ & 筋電図 & $\begin{array}{l}\text { 再生促進 } \\
\text { 効果あり }\end{array}$ \\
\hline $\operatorname{Roman}^{13)}, 1987$ & $\begin{array}{l}\text { ラット, 坐骨神経 } \\
\text { 切断・グラフト縫合 }\end{array}$ & $\begin{array}{l}\text { 陰極をグラフト上, } \\
10 \mu \mathrm{A}, 24 \text { 時間/日, } 21 \text { 日間 }\end{array}$ & 組織学的 & $\begin{array}{l}\text { 再生促進 } \\
\text { 効果あり }\end{array}$ \\
\hline Politis $^{14)}, 1988$ & $\begin{array}{l}\text { ラット，坐骨神経 } \\
\text { 切断・縫合 }\end{array}$ & $\begin{array}{l}\text { 陰極を遠位, } \\
1.5 \mu \mathrm{A}, 24 \text { 時間/日，18 日間 }\end{array}$ & 組織学的 & $\begin{array}{l}\text { 再生促進 } \\
\text { 効果あり }\end{array}$ \\
\hline Kerns $^{15)}, 1991$ & $\begin{array}{l}\text { ラット, 坐骨神経 } \\
\text { 切断・縫合 }\end{array}$ & $\begin{array}{l}\text { 陰極を遠位， } \\
0.6 \mu \mathrm{A} ， 24 \text { 時間/日，7 日間 }\end{array}$ & 組織学的 & $\begin{array}{l}\text { 再生促進 } \\
\text { 効果あり }\end{array}$ \\
\hline Kerns $^{16)}, 1992$ & $\begin{array}{l}\text { ラット，坐骨神経 } \\
\text { 挫滅 }\end{array}$ & $\begin{array}{l}\text { 陰極を遠位， } \\
10 \mu \mathrm{A} ， 24 \text { 時間/日，28 日 }\end{array}$ & $\begin{array}{l}\text { 組織学的, } \\
\text { 機能検査 }\end{array}$ & $\begin{array}{l}\text { 再生促進 } \\
\text { 効果あり(わずか) }\end{array}$ \\
\hline McGinnis $^{17)}, 1992$ & $\begin{array}{l}\text { モルモット, 腓骨神経 } \\
\text { 切断・縫合/挫滅 }\end{array}$ & $\begin{array}{l}\text { 陰極を遠位, } \\
20 \mu \mathrm{A}, 24 \text { 時間/日，45 日間 }\end{array}$ & $\begin{array}{l}\text { 組織学的, } \\
\text { 機能検查 }\end{array}$ & 再生抑制あり \\
\hline Hanson $^{18)}, 1994$ & $\begin{array}{l}\text { ラット, 坐骨神経 } \\
\text { 切断・グラフト縫合 }\end{array}$ & $\begin{array}{l}\text { 陰極をグラフト上, } \\
10 \mu \mathrm{A}, 24 \text { 時間/日，21 日間 }\end{array}$ & 組織学的 & 再生抑制あり \\
\hline
\end{tabular}


表 1 に示す. McDevitt ら ${ }^{12)}$ は，ラットの坐骨神 経を挫滅させ，足関節に陰極，側腹部に陽極をお いて損傷部位をはさんで一定電流を流し，経時的 に筋電図による評価を行った。そして電気刺激群 で神経の伸長が早くなることを示し，神経再生が 陰極方向に誘導されているとした. Roman $ら^{13)}$, Politis $5^{14)}$, Kerns $ら^{15,16)} も$ ，電気刺激 群で再生軸索の密度が高い, 特にミエリン化した 軸索が多い，血管が豊富であるなど，電気刺激が 神経再生や成熟を促進させていると考えられる組 織学的所見を認めたとした。一方，1990 年代に 入って Hanson ら ${ }^{18)}$ は，上記の一連の報告の見 直しを行い，電場が不安定である，標本数が少な いなどの問題点を挙げ，追実験を行ったところ， 直流電流による神経再生の促進はなく，むしろ抑 制が認められたとした。そして抑制の原因とし て, 直流電流によって電気分解が生じ，その分解 物質であるへリウムなどが，再生神経の伸長やシ ュワン細胞などの遊走を妨げると推測した。

\section{（2）パルス電気刺激と神経再生}

1980 年代後半から，パルス電気刺激による神 経再生への影響が報告されるようになった。これ らは, 直流電流を用いて弱い電場を定常的にかけ ている前述の一連の報告とは違い，脱分極閾值程 度の強さの電気刺激を，損傷神経の再生部（成長 円錐部）にかけている，培養細胞では，Manivannan $~^{19)}$ が, 神経細胞の成長円錐部を直接パ ルス電気で刺激し刺激部からの神経の発芽を記録
した。この現象は, 細胞外の培地からカルシウム イオンを除くと認められなくなり，電気刺激によ つて電圧依存性カルシウムチャンネルが開いて細 胞内にカルシウムイオンが流入し, 神経発芽の刺 激となったと考えられた。一方，動物実験では， 表 2 に示すように，脱分極閾值かそれ以上の電気 強度で，1〜 $20 \mathrm{~Hz}$ の刺激頻度（神経線維個々の 生理的発射頻度に近い頻度）で，損傷部のすぐ近 位の成長円錐部（神経再生を促す部分）をパルス 電気刺激する方法によりいくつかの報告がなされ ている. Nix ら ${ }^{20)}$ はウサギの坐骨神経挫滅モデ ルに, 脱分極閾值の 1.5 倍の電気強度・ $4 \mathrm{~Hz}$ に て刺激を行った結果，非刺激群に比して，より早 く，機能的にも良好な神経再生を得たとし，パル ス電気刺激により正常な状態の神経と同じような 電気的な興奮と，それによる感覚入力パターンが 与えられることにより機能的な神経連絡が保たれ ると考察した. Pockett ら ${ }^{21)}$ は，坐骨神経挫滅 モデルで損傷直後からパルス電気刺激をした群で 機能回復が早く, 刺激開始が 1 時間遅れても効果 が低くなるとした。この結果から，電気刺激は神 経細胞体への作用のほかに，成長円錐部への直接 作用による発芽の促進，ならびにワーラー変性や シュワン細胞からの神経栄養因子の分泌といった 初期の反応促進により再生速度を早くしているの ではないかと推定した。さらに，Al-Majed ら 22 は，混合神経である大腿神経の切断・縫合モデル でパルス電気刺激を行い，神経再生が早くなると

表 2 パルス電気刺激と神経再生

\begin{tabular}{|c|c|c|c|c|}
\hline 報 告 & 実験モデル & 刺激条件 & 評価法 & 総合評価 \\
\hline $\mathrm{Nix}^{20)}, 1983$ & $\begin{array}{l}\text { ウサギ, 坐骨神経 } \\
\text { 挫滅 }\end{array}$ & $\begin{array}{l}\text { 損傷部より近位部刺激, } \\
0.2 \mathrm{msec} \text { パルス幅, } 4 \mathrm{~Hz}, \\
\times 1.5 \text { 閾值強度, } 24 \text { 時間/日, } \\
1 \sim 14 \text { 日 }\end{array}$ & $\begin{array}{l}\text { 筋電図, } \\
\text { 機能検査 }\end{array}$ & $\begin{array}{l}\text { 再生促進 } \\
\text { 効果あり }\end{array}$ \\
\hline Pockett $^{21)}, 1985$ & $\begin{array}{l}\text { ラット, 坐骨神経 } \\
\text { 挫滅 }\end{array}$ & $\begin{array}{l}\text { 損傷部をはさんで刺激, } \\
0.1 \mathrm{msec} \text { パルス幅, } 1 \mathrm{~Hz} \text {, } \\
\times 1 \text { 閾值強度, } 0.25 \sim 1 \text { 時間/日 } \\
0 \sim 14 \text { 日 }\end{array}$ & 機能検査 & $\begin{array}{l}\text { 再生促進 } \\
\text { 効果あり }\end{array}$ \\
\hline Al-Majed ${ }^{22)}, 2000$ & $\begin{array}{l}\text { ラット, 大腿神経 } \\
\text { 切断・縫合 }\end{array}$ & $\begin{array}{l}\text { 損傷部より近位部刺激, } \\
0.1 \mathrm{msec} \text { パルス幅, } 20 \mathrm{~Hz}, \\
\text { 閾值以上の強度, } 1 \text { 時間/日, } \\
0 \sim 14 \text { 日 }\end{array}$ & 組織学的 & $\begin{array}{l}\text { 再生促進 } \\
\text { 効果あり }\end{array}$ \\
\hline Chen $^{23)}, 2001$ & $\begin{array}{l}\text { ラット, 坐骨神経 } \\
\text { 切断・グラフト縫合 }\end{array}$ & $\begin{array}{l}\text { 損傷部をはさんで刺激, } 2 \mathrm{~Hz} \text {, } \\
\times 1 \text { 閾值強度, } 0.25 \text { 時間/日 } \\
7 \sim 42 \text { 日 }\end{array}$ & 組織学的 & $\begin{array}{l}\text { 組織学上神経成熟の } \\
\text { 促進は認めるが, 再 } \\
\text { 生の成功率は低い }\end{array}$ \\
\hline
\end{tabular}


同時に，正確になるとした，すなわち，電気刺激 で神経再生が早くなると，Brushartらのいう “Preferential Motor Reinnervation” の過程が早 まり，より正確な神経支配が早く成立するとし た。そしてこの電気刺激の効果は，テトロドトキ シンの投与で阻害されることから，神経細胞体の レベルで起こっていると考察した。一方, Chen $ら^{23)}$ は，坐骨神経の切断・グラフト縫合のモデ ルで, パルス電気刺激を行い, 組織学的には血管 や軸索の密度が高いなど神経の成熟の促進を認め たとしながらも，刺激群では，非刺激群に比べて 再生の成功率が低いとした。この場合の再生の成 功率とは, 評価時肉眼的にグラフト内が再生線維 でつながっていることを示し，この結果から神経 成熟期には電気刺激は有効と考えられるが，神経 伸長期にはその効果が一定せず，不利にも働きう ると考察した。

これらの結果をまとめると，神経再生部を含ん で弱い電場を定常的にかけるような実験系におい ては，培養細胞では陰極方向に神経突起の伸長が 認められるが，動物実験ではその効果は不定とい える．これに対しパルス電気刺激では，動物実験 においても，それぞれの実験系で異なる作用点を 指摘しているが，効果が示されているものが多 い.こうした基礎実験の結果を外挿すると，臨床 的にも，神経縫合術時に縫合部やグラフト直上に 刺激電極を植えこみ, 再生初期からパルス電気刺
激をするという方法により，有効性が期待できる と考えられ，今後検討を要する。一方，現在リ八 の臨床で用いているような表面電気刺激では刺激 位置や強度を適正に設定することが困難で有効性 については不明であり，刺激部位や強度，または 刺激の開始時期が不適切な場合には, 再生の阻害 も起こりうると考えられる。

\section{2） 光の他の物理療法}

その他の神経再生を促進しうる物理療法とし て，レーザーや，超音波治療が報告されている。

レーザーに関しての報告はまだ少ないが，弱い レーザーで細胞分裂が促進されたという基礎の報 告と, ラットで受傷直後に用いると損傷による神 経細胞死を抑制し, 再生過程も早めるという報 告 ${ }^{24)}$ があり, 再生の初期過程, 変性神経の除去 過程や神経発芽に影響を与えていると考えられて いる.

超音波は，細胞膜の透過性を変えてカルシウム イオンを流入させることによってさまざまな代謝 を促進すると考えられており，骨折後の遷延治癒 などにはすでに臨床応用されている．神経再生に おいては，特に受傷 1 週間以内のマクロファージ の関与する過程, 変性物質の除去や再生因子の産 生などに影響を与えるという報告がある ${ }^{25)}$.

\section{3）運動療法}

末梢神経損傷後の運動療法については, 表 3 に 示すように，1920 年代より報告がある。Vecchi

表 3 運動療法と神経再生

\begin{tabular}{|c|c|c|c|c|}
\hline 報 告 & 実験モデル & 運動負荷条件 & 評価法 & 総合評価 \\
\hline Vecchi, 1929 & $\begin{array}{l}\text { ラット, 坐骨神経, } \\
\text { 挫滅 }\end{array}$ & $\begin{array}{l}\text { ランニング } 1.5 \text { 時間/日 } \\
\text { 術後 } 0 \sim 12 \text { 日 }\end{array}$ & 組織学的 & $\begin{array}{l}\text { 軸索発芽増加 } \\
\text { 効果あり }\end{array}$ \\
\hline Hines, 1942 & $\begin{array}{l}\text { ラット，脛骨神経, } \\
\text { 挫滅 }\end{array}$ & $\begin{array}{l}\text { ランニング } 2 \text { 時間/日, } \\
\text { 滑車, 水泳 } 1 \text { 時間/日 } \\
0 \sim 21 \text { 日 }\end{array}$ & $\begin{array}{l}\text { 組織学的, } \\
\text { 機能検查 }\end{array}$ & $\begin{array}{l}\text { 筋クレアチニン・筋重量増加, 等尺性 } \\
\text { 収縮力増強効果あり }\end{array}$ \\
\hline Gutmann, 1963 & $\begin{array}{l}\text { ラット，坐骨神経, } \\
\text { 挫滅 }\end{array}$ & $\begin{array}{l}\text { 水泳 3〜4 時間/日 } \\
0 \sim 35 \text { 日 }\end{array}$ & 組織学的 & $\begin{array}{l}\text { 軸索発芽増加あるが，軸索径は低下， } \\
\text { 軸索の数は有意差なし }\end{array}$ \\
\hline Crockett, 1975 & $\begin{array}{l}\text { モルモット, } \\
\text { 脛骨・腓骨神経, } \\
\text { 切断・縫合 }\end{array}$ & $\begin{array}{l}\text { ランニング } 0.5 \text { 時間/日 } \\
8 \sim 180 \text { 日 }\end{array}$ & $\begin{array}{l}\text { 組織学的, } \\
\text { 機能検査 }\end{array}$ & $\begin{array}{l}\text { 筋重量・筋タンパク量, 等尺性収縮力 } \\
\text { 共に有意差なし }\end{array}$ \\
\hline Herbison, 1980 & $\begin{array}{l}\text { ラット，坐骨神経, } \\
\text { 挫滅 }\end{array}$ & $\begin{array}{l}\text { ランニング 1〜2 時間/日 } \\
\text { 14〜 } 42 \text { 日 }\end{array}$ & $\begin{array}{l}\text { 組織学的, } \\
\text { 機能検查 }\end{array}$ & 筋線維径, 等尺性収縮力共に有意差な \\
\hline Badke $^{26)}, 1989$ & $\begin{array}{l}\text { ラット, 脛骨神経, } \\
\text { 切断・縫合 }\end{array}$ & $\begin{array}{l}\text { ランニング } \\
0 \sim 60 \text { 日 }\end{array}$ & $\begin{array}{l}\text { 組織学的, } \\
\text { 機能検査 }\end{array}$ & $\begin{array}{l}\text { シナプス伝達の成熟促進はあるが, 神 } \\
\text { 経再支配は遅延する }\end{array}$ \\
\hline Meeteren $^{27)}, 1997$ & $\begin{array}{l}\text { ラット, 脛骨神経, } \\
\text { 挫滅 }\end{array}$ & $\begin{array}{l}\text { 爪先立ち } \\
0 \sim 24 \text { 日 }\end{array}$ & $\begin{array}{l}\text { 筋電図, } \\
\text { 機能検查 }\end{array}$ & $\begin{array}{l}\text { 早期の機能回復があり, 伝導速度も改 } \\
\text { 善効果あり }\end{array}$ \\
\hline
\end{tabular}


らは, 神経挫滅後すぐに運動負荷し, 組織学的に 再生軸索の発芽が増えたとしたが, Crockett ら は神経切断・縫合モデルで運動負荷を行い, 組織 学的にも筋力的にも有利な所見はなかったとし た。また Badke ら ${ }^{26)}$ は，マウスの脛骨神経切 断・縫合モデルで術直後より運動負荷を行い, 神 経再支配（伸長）は遅延するが，筋収縮力やシナ プス伝達の成熟には有利であったとした。このよ うに傷害モデルや運動負荷量, 開始時期がさまざ まであり, 運動の神経再生促進効果の有無につい ての結論は一定していなかった。これに対して Meeteren ら 27) は，ストレスは内因性ステロイド の分泌増加や交感神経系の働きによる血管収縮を 引き起こして神経損傷後の神経再生を遅延させる とし，運動がマイナスの効果を示しているものは 運動負荷が強すぎるか, 運動課題そのものがスト レスとなり神経再生に悪影響を与えているのでは ないかと仮定した。そこでラットの坐骨神経挫滅 モデルで，軽い運動負荷を受傷直後よりかけ，機 能検査と電気生理学的検査で評価した ${ }^{28)}$. その結 果, 軽運動負荷群では非運動群に比べて機能改善 が早く, 神経伝導速度も早期に回復してその効果 が持続することを示し，運動は神経発芽や伸長， 再生軸索の成熟やミエリン化の促進効果があるこ とを示唆した。なお，ここでの軽い運動負荷と は, ラットに一日 4 時間, 背伸びをしないと届か ないような場所に水をおいて，背伸びの運動をさ せるというものである。

運動療法の神経再生促進効果については次のよ うにまとめられる。第 1 に運動による効果が示さ れている報告も多いが, 運動強度が強すぎるなど ストレスとなりうる負荷は再生に不利に働く可能 性がある．第 2 に，神経挫滅後には初期から運動 負荷をかけることによる神経再生促進効果が期待 される、ただし，切断・縫合の場合には，直後の 関節運動が血管再生の遅れや瘷痕組織の増生を引 き起こし，神経再生の妨げになるという報告 ${ }^{29)} も$ あり, 直後の運動療法は避けるべきと考えられる.

\section{4）中枢性代償}

これまで述べてきた外科的治療, 物理療法, 運 動療法は神経再生の促進を期待するものであった
が, 末梢神経再生のもう 1 つの問題点である過誤 神経支配に対しては，中枢での代償を用いて機能 回復を目指すことがアプローチの中心となってい る.

\section{（1）運動神経の過誤支配と機能回復}

過誤神経支配とその後の中枢性代償のメカニズ ムを考える上でのモデルとして，運動神経では人 為的な過誤神経支配を臨床に応用した，肋間神経 移行術がある。これは腕神経叢麻痺において肘屈 曲機能再獲得のため, 肋間神経を筋皮神経に縫合 するものだが, 最初呼吸に伴っての肘の屈曲のみ 可能であった患者が, 段々に呼吸と関係なく随 意的に肘屈曲を行うことが可能となっていく. Malessy ら ${ }^{30)}$ は, 肋間神経移行術後の患者を運 動誘発電位 (motor evoked potential, MEP) で 評価し, 神経移行後の时屈曲に関わるのはもとも と肘屈曲を司っていた運動野領域であることを示 した。そして，大脳レベルで肘屈曲の運動野と肋 間神経運動野の連絡ができるか，脊髄レベルで連 絡ができると推測したが，1980 年代に行われた ネコの交叉神経縫合による実験 ${ }^{31)}$ で中脳赤核脊 髄路細胞でシナプスの発芽新生が見出されている ことから, 肋間神経移行術においても大脳レベル で運動野の連絡ができているという説のほうが可 能性が高いとした．ただしこの連絡がまったく新 しく形成されたとは考えにくく，腕を動かすとき に姿勢をコントロールするために両運動野にもと もとある神経連絡が，訓練によって増強されたと 考察した。このように，運動神経末梢で過誤支配 による神経支配の変化があっても，もともとある 程度の連絡のある運動野間であれば，運動野にお ける可変性を利用してリハを行い，機能回復を得 ることができると考えられる。その他の例とし て, 未梢性顔面神経麻痺後の異常共同運動に対し バイオフィードバックの効果を示した報告 ${ }^{32}$ が あり，中枢性の代償によると考察されているが, 大脳生理学的な検討はされていない.

\section{(2) 知覚再教育}

感覚神経間の過誤支配による感覚の異常は，末 梢神経損傷後, 縫合などの処置がなされても生じ 易く，臨床上の問題となっている．末梢神経損傷 


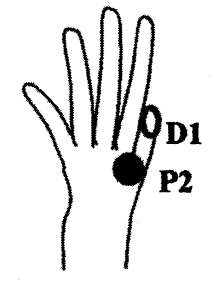

正中神経切断・ 路合

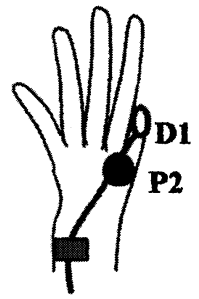

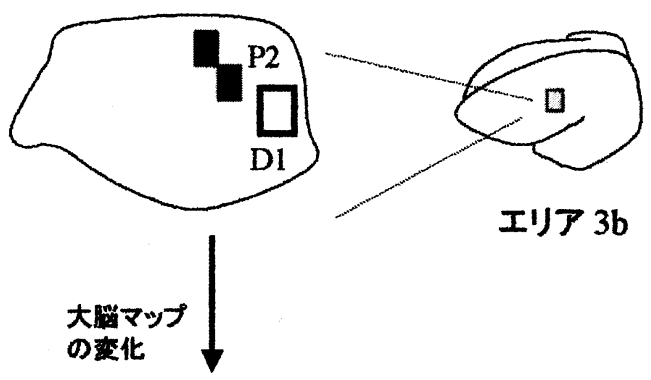
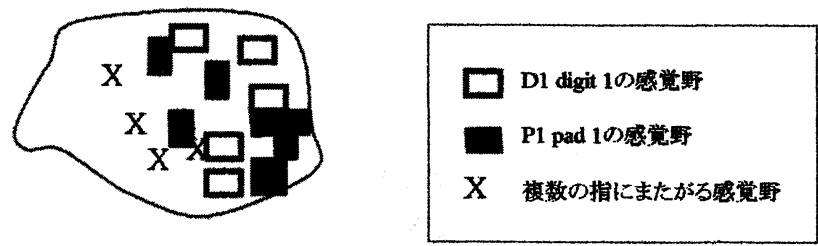

図 2 神経切断・縫合後の大脳マップの変化（文献 33 より抜粋） サルの手の感覚野（エリア $3 \mathrm{~b}$ ) では，指などの各部位が正確にマッピングされている が, 正中神経切断・縫合術後には, 感覚マップは混乱する.

後の大脳感覚野マップの変化については 1980 年 代よりサルを用いて研究されている。サルの手の 感覚野はエリア $3 b$ といわれ，正常ではそれぞれ の指や部分が細かくマッピングされている. Wall ら ${ }^{33)}$ は，成体サルにて，正中神経を切断・ 縫合し，その後の感覚マップの変化を報告した。 末梢においては, 正中神経切断・縫合後, 神経再 生過程で感覚神経間のミクロの過誤神経支配が起 こり, 無秩序に皮膚感覚を再支配する.それに伴 い, エリア $3 \mathrm{~b}$ の正中神経領域の感覚マップは混 乱し，1つの箇所の感覚をさまざまな感覚野で感 じたり，複数の指にわたる受容野の出現などを認 めるようになることを示した（図 2).これが, 臨床的には, 皮膚位置感覚の異常や低下につなが ると考察した。一方, 胎児期のサルでは, 末梢で 無秩序な神経再支配が起こっても，大脳 $3 \mathrm{~b}$ 野に おける感覚マップは正常に近くなり，胎児期には 感覚マップを再構築させる大脳の適応代償機能が あることが示されている ${ }^{34)}$.このように，成体で は大脳の感覚マップを末梢での神経支配の変化に 応じて再構築することは容易ではないことが報告 されているが, Florence ら ${ }^{35)}$ は, 神経再生時期 に感覚入力を増やすことによってよりよい感覚マ ップが再構築されることを示した. 先の報告と同
じく，サルの正中神経を切断・縫合したのち，手 術をした手をなるべく使って細かい作業をするよ うなタスクを与えた群を 'Sensory Enrichment' 群とし，タスクを与えない対照群と，手術した手 を使わせないようにした 'Sensory Restricted’ 群 の 3 群で, 3.5 力月後の大脳感覚野の手指のマッ プを比較した．この報告では，手指の各部位を細 かく特異的にマッピングできた感覚受容野部分が 多いことを，感覚機能がよいと評価している，そ の結果, 'Sensory Enrichment'群で最も正確な マップが再構築され，より良い感覚機能が獲得で きたという結果が導かれている(図 3)。この実 験は幼若なサルをつかってなされており，成体で 同じ効果が得られるかという問題はあるが，感覚 入力の増加という手段によって, 感覚マップの再 構築が促進されるという結果は，ヒトにおけるい わゆる知覚再教育の有用性を支持する内容である と考えられる．ただし，感覚入力を増やすといっ ても意味のない単純な刺激を加えるだけでは感覚 マップの改善はないとされ，動物でいえばエサな どの報償と結びついた刺激，ヒトであれば言語的 な指示や視空間認知と結びつけて感覚刺激をする ことが感覚機能の改善に有効であると考えられて いる ${ }^{36)}$. 


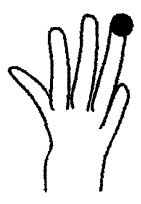

small

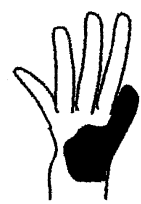

large

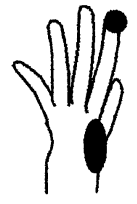

multiple

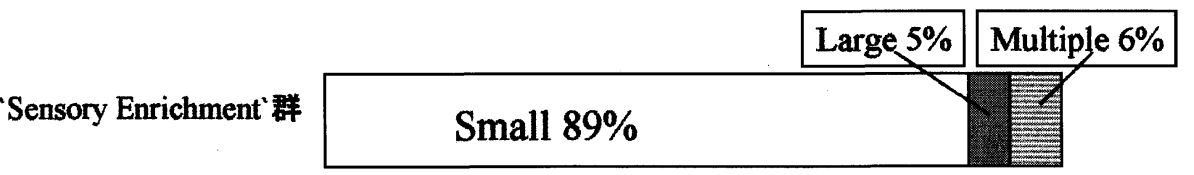

対照群

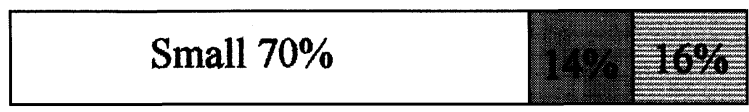

\section{'Sensory Restricted’群}

Small 49\%

図 3 'Sensory Enrichment'による感覚マップの変化（文献 35 より改変）

Florence らは, 'Sensory Enrichment’ の効果の評価として, 訓練後のサルの手指の大脳感覚マップの評価を行った。 ‘Small’ は，手指の限局した部位が大脳のある感覚受容野に対応しているもの，'Large'は手指の広範囲が，'Multiple’ は 手指のいくつかの部位がある感覚受容野に対応しているものとした（無処置のサルでは, 感覚受容野はほぼすべて ‘Small’ に分類される)。そして Small/Large/Multipleに分類される感覚受容野部分の出現頻度で, 'Sensory Enrichment'群/対 照群/‘Sensory Restricted’群を比較した。そその結果 ‘Sensory Enrichment’群では，他の群に比べ，'Small’に分類される 感覚受容野部分の割合が有意に高く，より正確な感覚マップが再構成されたとした.

\section{ま と め}

末梢神経損傷後の神経再生の促進因子として, 神経栄養因子などの研究が活発になされている が，電気刺激や運動療法など，古くからリ八の場 面で利用されていた手段もその有効性の再評価が されるべきと考えられる。特に電気刺激に関して は，むしろ神経再生の阻害となるという報告がイ ンパクトを持ってなされたこともあり，その後の 臨床研究は非常に少なくなっている。しかし，動 物実験レベルでは有効と考えられる刺激条件が次 第に確立されてきており，今後の臨床応用が期待 される. 末梢神経再生後の感覚神経過誤支配に対 する中枢性代償についても，動物実験レベルでは 感覚入力を増やすリハの有効性が示されている. こうしたリハは動物よりも，ヒトでより効果的に 行うことができると考えられるので，臨床におけ る評価と検討が今後望まれる。

\section{文献}

1) Fu SY, Gordon $T$ : The cellular and molecular basis of peripheral nerve regeneration. Mol Neurobiol 1997 ; 14: 67-116

2）川口三郎 編 : 神経再生と機能修復. Clin Neurosci $2000 ; 18: 1245-1276$

3) Brushart TM : Motor axons preferentially reinnervate motor pathways. J Neurosci 1993 ; 13: 27302738

4) Martini R, Schachner M, Brushart TM: The L2/ HNK-1 carbohydrate is preferentially expressed by previously motor axon-associated Schwann cells in reinnervated peripheral nerves. J Neurosci 1994; 14: 7180-7191

5) Maki Y, Yoshizu T, Tajima T, Narisawa H: The selectivity of motor axons during regeneration with sensory axons. J Reconstr Microsurg 1996; 12: 553-557

6) Madison RD, Archibald SJ, Brushart TM : Reinnervation accuracy of the rat femoral nerve by motor and sensory neurons. J Neurosci 1996 ; 16 : 56985703

7) Dagum AB : Peripheral nerve regeneration, repair, and grafting. J Hand Ther 1998; 11 : 111-117

8) Hadlock T, Elisseeff J, Langer R, Vacanti J, Cheney $\mathrm{M}$ : A tissue-engineered conduit for peripheral nerve repair. Arch Otolaryngol Head Neck Surg 
$1998 ; 124: 1081-1086$

9) Tiangco DA, Papakonstantinou KC, Mullinax KA, Terzis JK: IGF-I and end-to-side nerve repair: a dose-response study. J Reconstr Microsurg 2001; 17 : 247-256

10) Joung I, Kim HS, Hong JS, Kwon H, Kwon YK : Effective gene transfer into regenerating sciatic nerves by adenoviral vectors: potentials for gene therapy of peripheral nerve injury. Mol Cells 2000; 10 : $540-545$

11) McCAIG CD : Nerve branching is induced and oriented by a small applied electric field. J Cell Sci 1990 ; 95 : 605-615

12) McDevitt L, Fortner P, Pomeranz B : Application of weak electric field to the hindpaw enhances sciatic motor nerve regeneration in the adult rat. Brain Res 1987 ; 416 : 308-314

13) Roman GC, Strahlendorf HK, Coates PW, Rowley BA : Stimulation of sciatic nerve regeneration in the adult rat by low-intensity electric current. Exp Neurol 1987; 98 : 222-232

14) Politis MJ, Zanakis MF, Albala BJ : Facilitated regeneration in the rat peripheral nervous system using applied electric field. J Trauma 1988; 28(9) : 1375-1381

15) Kerns JM, Fakhouri AJ, Weinrib HP, Freeman JA : Electrical stimulation of nerve regeneration in the rat: the early effects evaluated by a vibrating probe and electron microscopy. Neuroscience 1991 ; 40 : 93-107

16) Kerns JM, Lucchinetti C : Electrical field effects on crushed nerve regeneration. Exp Neurol 1992; 117 : 71-80

17) McGinnis ME, Murphy DJ : The lack of an effect of applied d.c. electric field on peripheral nerve regeneration in the guinea pig. Neuroscience $1992 ; \mathbf{5 1}$ : 231-244

18) Hanson SM, McGinnis ME: Regeneration of rat sciatic nerves in silicone tubes : characterization of the response to low intensity d.c. stimulation. Neuroscience 1994 ; 58: 411-421

19) Manivannan $S$, Terakawa $S$ : Rapid sprouting of filopodia in nerve terminals of chromaffin cells, PC 12 cells, and dorsal root neurons induced by electrical stimulation. J Neurosci 1994 ; 14 : 59175928

20) Nix WA, Hoph HC: Electrical stimulation of regenerating nerve and its effect on motor recovery. Brain Res 1983 ; 272 : 21-25

21) Pockett S, Gavin RM : Acceleration of peripheral nerve regeneration after crush injury in rat. Neurosci Lett 1985 ; 59 : 221-224

22) Al-Majed AA, Neumann CM, Brushart TM, Gordon $\mathrm{T}$ : Brief electrical stimulation promotes the speed and accuracy of motor axonal regeneration. J Neurosci $2000 ; 20$ : 2602-2608

23) Chen YS, Hu CL, Hsieh CL, Lin JG, Tsai CC, Chen $\mathrm{TH}$, Yao $\mathrm{CH}$ : Effects of percutaneus electrical stimulation on peripheral nerve regeneration using silicone rubber chambers. J Biomed Mater Res $2001 ; 57$ : 541-549

24) Rochkind S, Ouaknine GE: New trend in neuroscience: low power laser effect on peripheral and central nervous system (basic science, pre-clinical, clinical studies). J Neurol Res $1992 ; 14: 2-11$

25) Lazar DA, Curra FP, Mohr B, McNutt LD, Kliot M, Mourad PD : Acceleration of recovery after injury to the peripheral nervous system using ultrasound and other therapeutic modalities. Neurosurg Clin North Am $2001 ; 12$ : 353-357

26) Badke A, Irintchev AP, Wernig A : Maturation of transmission in reinnervated mouse soleus muscle. Muscle Nerve $1989 ; \mathbf{1 2}$ : 580-586

27) Meeteren NLU, Brakkee JH, Helders PJM, Wiegant VM, Gispen WH: Functional recovery from sciatic nerve crush lesion in the rat correlates with individual differences in responses to chronic intermittent stress. J Neurosci Res 1997 ; 48 : 524532

28) Meeteren NLU, Brakkee JH, Hamers FPT, Helders PJM, Gispen WH: Exercise training improves functional recovery and motor nerve conduction velocity after sciatic nerve crush lesion in the rat. Arch Phys Med Rehabil 1997 ; 78: 70-77

29) Lee WPA, Constantinescu MA, Butler PEM : Effect of early mobilization on healing of nerve repair: histologic observation in a canine model. Plast Reconstr Surg 1999; 104: 1718-1725

30) Malessy MJA, van der Kamp W, Thomeer RTWM, van Dijk JG: Cortical excitability of the biceps muscle after intercostal-to-musculocutaneous nerve transfer. Neurosurgery $1998 ; 42: 787-795$

31) Fujito $Y$, Tsukahara N, Oda Y : Formation of functional synapses in the adult cat red nucleus from the cerebrum following cross-innervation of forelimb flexor and extensor nerves. Exp Brain Res $1982 ; 45$ : 13-18

32) Ross B, Nedzelski JM, McLean JA: Efficacy of feedback training in long-standing facial nerve paresis. Laryngoscope 1991 ; 101 : 744-750

33) Wall JT, Kaas JH, Sur M, Nelson RJ, Felleman DJ, Merzenich MM: Functional reorganization in somatosensory cortical areas $3 \mathrm{~b}$ and 1 of adult monkeys after median nerve repair: possible relationships to sensory recovery in humans. J Neurosci $1986 ; 6$ : 218-233

34) Florence SL, Jain N, Pospichal MV, Beck PD, Sly $\mathrm{DL}, \mathrm{Kaas} \mathrm{JH}$ : Central reorganization of sensory pathways following peripheral nerve regeneration in fetal monkeys. Nature 1996 ; 381 : 69-71

35) Florence SL, Boydston LA, Hackett TA, Lachoff HT, Strata F, Niblock MM : Sensory enrichment after peripheral nerve injury restores cortical, not thalamic, receptive field organization. Eur J Neurosci $2001 ; 13$ : 1755-1766

36) Lundborg G: Brain plasticity and hand surgery: an overview. J Hand Surg 2000 ; 25B : 242-252 